\title{
Muséologies
}

Les cahiers d'études supérieures

\section{The exhibition as medium: Artist, space, artwork and viewer in dialogue}

\section{Teresa Azevedo}

Volume 8, numéro 1, 2015

Réflexions sur la pratique curatoriale et la recherche-création

URI : https://id.erudit.org/iderudit/1034612ar

DOI : https://doi.org/10.7202/1034612ar

Aller au sommaire du numéro

Éditeur(s)

Association Québécoise de Promotion des Recherches Étudiantes en Muséologie (AQPREM)

ISSN

1718-5181 (imprimé)

1929-7815 (numérique)

Découvrir la revue

Citer cet article

Azevedo, T. (2015). The exhibition as medium: Artist, space, artwork and

viewer in dialogue. Muséologies, 8(1), 91-113. https://doi.org/10.7202/1034612ar

Tous droits réservés (C Association Québécoise de Promotion des Recherches Étudiantes en Muséologie (AQPREM), 2016
Ce document est protégé par la loi sur le droit d'auteur. L’utilisation des services d'Érudit (y compris la reproduction) est assujettie à sa politique d'utilisation que vous pouvez consulter en ligne.

https://apropos.erudit.org/fr/usagers/politique-dutilisation/ 
Article quatre

\section{The exhibition as medium: artist, space, artwork and viewer in dialogue ${ }^{1}$}

Teresa Azevedo

1 This paper follows my current $\mathrm{PhD}$ investigation about the role of the artist's studios in the artistic and museological practices. Although not directly related with the subject of the artist's studio, the inventory work I developed at Alberto Carneiro's studio made me realize the importance of the exhibition as a means to enhance some features of his works which are usually not perceived. This ongoing investigation is funded by a PhD research grant by FCT (Technology and Science Foundation, Portugal). 
The author graduated in Art History at Porto's University, Portugal (2004), where she also took her Master in Art Studies, specialization in Museum and Curatorial Studies (2008). She worked in projects concerning museum objects' inventory-at Porto University's Museums (2007) and House Museum Afonso Lopes Vieira in São Pedro de Moel (2011) — and documental researchat Serralves Museum (2006 and 2009) and Architect Marques da Silva Foundation, Porto (2009 and 2011). In 2012 she collaborated on the inventory (using open source program CollectiveAccess) of sculptor Alberto Carneiro's works and archival documents, working directly from his studio, and in 2013 she was a researcher in the project Documentation of Contemporary Art (FCT, IHA/FCSH/UNL). Currently she is a researcher at Art History Institute (Social and Human Sciences Faculty, New University, Lisbon) and a PhD student in Museum Studies at Porto's University with a research grant by Technology and Science Foundation. Interested in the documentation and musealisation of contemporary art, she develops her investigation on the role of the artist's studios in their process of work and creation. teresa.c.azevedo@gmail.com 


\section{Introduction}

In this paper I intend to explore the notion of the exhibition as an opportunity to reveal and enhance meaning in independent but related artworks (project-drawings and installation artworks), using as examples a selection of Alberto Carneiro's (Portugal, 1937) works. The goal is to reveal the added value of an exhibition strategy not usually used with these works in keeping with the artist's view that "the reading of the project favors a better perception of the work" 2 .

After a brief contextualization of Carneiro's production and description of the works taken as case-studies, this paper is organized in three chapters addressing as many topics: project-drawing vs autonomous drawing; exhibit drawing vs exhibit installation artworks; interpretation vs experience. By taking the exhibition as a medium and exploring the possible dialogues between project-drawings and installation artworks, I will suggest ways in which crucial features of Carneiro's work expand the exhibition space as a place of making meaning.

Carneiro's practice is extensive and complex, open to a variety of interpretations, and yet very coherent and based on a personal journey through life, art and nature addressed by the artist as a whole. My intention is not an exhaustive analysis of the selected works, but instead to open them to new readings.

\section{The artist and his works}

Alberto Carneiro ${ }^{3}$ is a Portuguese sculptor born in 1937 near Porto, Portugal. His work is invested in the activation of the totality of a visitor's senses in the exhibition space shared between them and the artwork, the importance of concept over its materialization, the use of language both as an aesthetic and communicative tool, and the use of and transposition to the exhibition space of natural materials. While his work is linked to some aspects of Minimal, Conceptual and Land Art it is never a direct reflex of those movements. Instead it is an appropriation of some of their concepts, combined with personal experience and relationship to nature which is unique within contemporary Portuguese sculpture. Alongside sculpture, drawing is a constant practice in Carneiro's work ${ }^{4}$, who uses it as a wide field of experimentation, exploring its double instance as research and product-whether in autonomous works or as part of installations or photographic series 5 .

This paper selects four artworks created between the end of the 1960s and the beginning of the 1970 s, as case-studies.

Edições Colibri e IHA - Estudos de Arte Contemporânea, FCSH - UNL, 2007; ALMEIDA, Bernardo Pinto de. Alberto Carneiro. Lição de Coisas. Porto: Campo das Letras, 2007; CARNEIRO, Alberto. arte vida / vida arte. Alberto Carneiro. Porto: Fundação de Serralves, 2013.

4 Not by chance, Carneiro was a drawing lecturer at Porto's University (from 1971 to 1976 in the Sculpture Course of ESBAP - Porto's University Superior School of Fine Arts; and from 1970 to 1999 in the Architecture Course of FAUP - Porto's University Architecture School), developing an educational program in which drawing was always related to the conception of project.

5 ROSENDO, Catarina. "A garden as far as the eye can see: paradise on earth" In ROSENDO, Catarina (ed.) Alberto Carneiro. Árvores, flores e frutos do meu jardim. Desenhose Esculturas. Lisbon: Documenta, Fundação Carmona e Costa, 2015, p. 183.
2 OLIVEIRA, Cristina. A preservação da arte efémer lúdico em sete imagens espelhadas. (Master's degree Thesis in Conservation and Restoration). Lisbon: Universidade Nova 3 With a career now with more than 50 years, Carneiro's work opens itself to many relevant readings, some of them are still unexplored in the theory about this artist. Nevertheless, there are a great number of important books and texts about his life and work which should be consulted for a more reading about the sculptor (one that was de Compostela: Centro Galego de Arte Contemporáne 2001; CARLOS, Isabel. Alberto Carneiro: a escultura é um pensamento. Vol. 34, Caminhos da arte portuguesa no século XX. Lisbon: Caminho, 2007; CARNEIRO, Alberto. Das notas para um diário e outros textos. Antologia. Lisbon: Assírio \& Alvim, 2007; ROSENDO, Catarina. Alberto Carneiro: os primeiros anos (1963-1975), Colecção Teses. Lisbon: 
All examples consist of two independent but interrelated works: a project-drawing and an installation artwork ${ }^{6}$ materializing the concepts developed in the former. The installation artwork succeeds the related project-drawing, and both devices always share the same title and creation date.

\section{O Canavial: memória-metamorfose de um corpo ausente (The Reedbed: memory-metamorphosis of an absent body $\left.y^{7}\right), 1968^{8}$}

The Reedbed ${ }^{9}$ was created in $1968^{10}$ and, as pointed out by Carneiro himself, is a crucial work in his career: it constituted a shift in aesthetics for the artist (as well as a new experience for the viewer), moving towards a symbolic and conceptual organization of natural materials in space, be it a sheet of paper or an exhibition room.

(fig.1) The project-drawing, made on graph paper ${ }^{11}$, is signed and dated in the bottom right corner and titled in the top left. It is a loaded document which informs the reader/viewer of not only the work's installation plans but a myriad of other subjects. Arrows indicate the artist's consideration of a viewer's path through the work, a detail of a single reed is annotated with a thought regarding "Nature

6 Carneiro distinguishes his installation artworks between what he calls involvements - works that can be surveyed by the viewer in an attempt to activate all the senses within the exhibition space - and works that occupy the entire exhibition space and can actually be entered by visitors who become part of the work. This concern with the physical presence of the viewer in the exhibition space which the viewer shares with the artwork is in line with some lessons of Minimal Art. See, for example, the work of Carl Andre, and the importance the artist gave to the "materiality of the sculptural object and the viewer's spatial encounter with it". Cf. MALONE, Meredith. "The Pourous Practice of Drawing: System, Seriality, and the Handmade Mark in Minimal and Conceptual Art”. In NACKMAN, Rachel (ed.). Notations: Contemporary Drawing as Idea and Process. Washington: Mildred Lane Kemper Art Museum, 2012. http://notations.aboutdrawing.org/essay/ (retrieved in April 2015)

7 Because the titles of the works play a very important role in the context of this analysis, and it is important to understand them, I will only present them in Portuguese in the first mention, and from then on always refer to them in English. All the translations of the titles and sentences written in the drawings are mine, with one exception, signaled in place. and its formal mastery'. A code with colors and letters is, according to the artist's notes: "Possible signs for the recreation of the absent body [...]". The careful viewer is even offered a glimpse of the origins of the work by reading the small text above the signature which connects the work to a specific memory and place: "From my childhood I kept the hours of enchantment of running around the fields (the flowers and the stolen fruits, the warbling of the birds, the grass immensely green; the brook passing by and the feeling of a body lying in the reedbed)".

(fig. 2) The Reedbed was partially materialized two years later, in 1972 (at Abel Salazar Gallery, Porto), and fully installed in 1973, in a solo exhibition at Quadrante Gallery, Lisbon. Following this each iteration of the work fills an entire room as projected by the artist in 1968. This installation consists of a variable number of reeds dispersed and adapted to the gallery space, occupying it intensively and creating a kind of labyrinth which should be traversed by the viewer. Because the reeds should occupy the space entirely, their number and configuration varies according to the exhibition space, but always creates a sensorial involvement which is one of the key concepts within most of Carneiro's creations ${ }^{12}$.

8 For a more complete and profound analysis of this and other works, as well as their relations with some crucial aspect of the artist's work, Cf. ROSENDO, Catarina. Alberto Carneiro: os primeiros anos (1963-1975)... op. cit.

9 In order to facilitate reading, I will be abbreviating the title of The Reedbed: Memory-Metamorfosis of an Absent Body, to The Reedbed.

10 Carneiro clearly situates the origin of this work in his room in London (where he studied at Saint Martins' School of Art from 1968 to 1970), in december 12 1968, where the title came to him as a memory related to his first notion of sexuality as a child at play. Cf. MELO, Alexandre.

“O viandante esclarecido." In Alberto Carneiro. Lisbon: Assírio \& Alvim, p. 18.

11 Alberto Carneiro started to use this graph paper in London, and it became the preferred background for this type of drawings. Curiously, many artists associated with Postminimalism or Process Art, like Barry Le Va or Mel Bochner, for example, frequently used graph paper. 12 ROSENDO, Alberto Carneiro: os primeiros anos (19631975)... op. cit., p. 92. See also Rosendo's description of this work, Ibid., pp. 92-93. 


\section{O Laranjal-Natureza Envolvente (The Orange Grove - Involving Nature), 1969}

This work was also created in London, between April and May 1969, in the form of a two-page project-drawing. Both pages are dated and signed at the bottom, and have the title written on top. On the first page the title is longer: "The orange grove - involving nature - involved senses: the vision, the earing, the tact, the smell and the taste. The orange grove and its images in the objective and subjective relations of the viewer in the path from the conscious to the unconscious and vice-versa"-clearly indicating one of the main characteristics of this installation: the activation of all the viewer's senses.

(fig. 3) One of the project-drawings presents plans for the installation of the work with different views and perspectives; the "possible penetration pathways" of the viewer into and around the installation; drawn details of an orange, with written notes describing the senses involved in eating the orange, smelling the orange, or stepping on the earth ${ }^{13}$. The drawing clearly shows three distinct spaces within the installation delimited by the earth on the floor, designated by the artist as "the conscious" (the place where the orange grove is); "the subconscious" (the central space); and "the unconscious" (the other end of the installation, where a cropped shape of the orange grove lays on the ground). The second project-drawing describes an audio record installed in the central space which should be heard throughout the entire exhibition space.

(fig. 4) The Orange Grove ${ }^{14}$ was materialized two years later, in a solo exhibition at Ogiva Gallery, Óbidos, Portugal, in 1971. It consists of a rectangular dirt floor, "on which rest, vertically, two sheets of metallic plate, $[. .$. constituting, in the void which separates them, an open cube $[\ldots]$ and dividing the dirt in three distinct parts." On one end, there is an orange grove planted in the dirt, with oranges lying around it. Opposing the metallic plate, which has a drawing of the tree on its exterior side, there is a representation of the shadow of the orange grove, made in raw cloth placed lengthwise on the floor. "A light focus, placed on the ground between the orange grove and the metallic place, works like an "orange of light, sprouting from the dirt"15". On the other end, the metallic plate has a cutout of the image of the orange grove, which falls lengthwise on the floor, opposite from the cloth on the other side. In the center, the two metallic plates face each other and form an open chamber, where, on the ground, an audio recording emerges, audible throughout the entire exhibition space ${ }^{16}$. It consists of the warbling of birds in different intensities, a feminine voice - the voice of the earth—reciting four texts about the history of the orange tree through the four seasons and four silence pauses.

(fig. 5) Besides the sight of the tree and its representations, the sound heard throughout the entire space, the touch of the different materials (natural or artificial), and the smell of the earth and the oranges, the activation of the sense of taste was achieved by the oranges pilled along the gallery walls, which should be eaten by viewers, who then became engaged in a full involvement of the senses.

Unlike the other installation artworks described in this paper which should be penetrated by the viewer, after the first materialization of The Orange Grove it became clear that stepping on the dirt would result in damaging the gallery floor. The artist himself ${ }^{17}$ admits that while the project originally intended movement through the soil, visitors are only allowed to move around it. (fig. 6)
13 As we will see in the next chapter, in a 2009 interview, the artist assumed that the earth should not be stepped on, and the viewer may simple survey or observe the work. 14 In order to facilitate reading, I will be abbreviating the title of The Orange Grove - Involving Nature, using just The Orange Grove.
15 ROSENDO, Catarina. Alberto Carneiro: os primeiros anos (1963-1975)... op. cit., pp. 161-162. My translation.

16 Ibid.

17 OLIVEIRA, op.cit., pp. 56-57. 


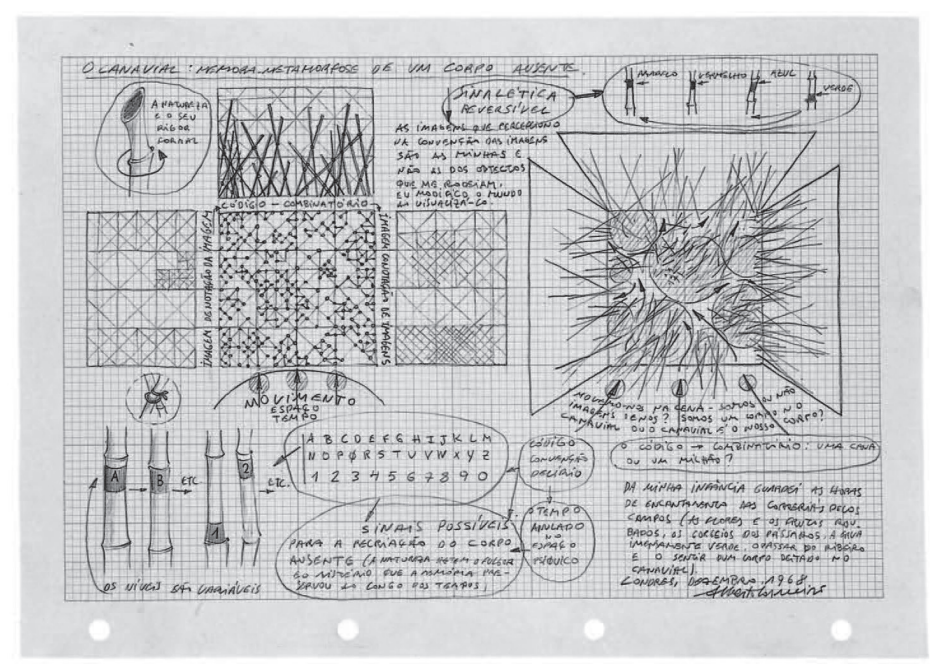

\section{Figure 1}

Alberto Carneiro, The Reedbed: memory-metamorphosis of an absent body, 1968 (project-drawing).

(C) Coll. Fundação Luso-Americana para o Desenvolvimento, on long-term loan to Fundação de Serralves - Museu de Arte Contemporânea, Porto [Photographer: Laura Castro Caldas/ Paulo Cintra]. Courtesy of FLAD.

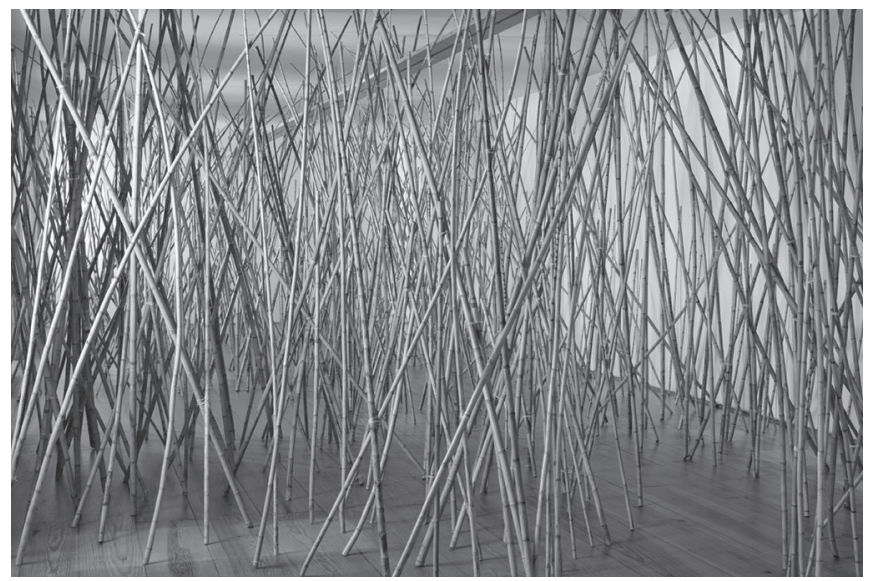

Figure 2

Alberto Carneiro, The Reedbed: memory-metamorphosis of an absent body, 1968. View of the installation at Grão Vasco Museum, Viseu, Portugal, 2010.

(C) 2010 DMF, Lisbon (rights reserved) [Photographer: Daniel Malhão]. Courtesy of CGD. 


\section{Uma linha para os teus sentimentos estéticos} (A line for your art-form-feelings ${ }^{18}$ ), 1970-71

The project-drawing was created in 1971 for "the use of space [...] of Alvarez Gallery"19, but it can be adapted to any other exhibition space. It contains a plan of the exhibition space viewed from the entrance of the gallery with the work installed on the walls, arrows on the floor showing the possible paths of the viewers through the space, a drawing of the side view of a head ${ }^{20}$, framing the correct height for the placement on the wall of the three lines that constitute the physical components of the work. The caption of the upper plans refers the door and window of the gallery ( $\mathrm{X}$ and $\mathrm{G}$ ), and the artist wrote "Penetration-outside to inside and vice-versa”, enhancing the importance of the movement of the viewer into the space.

(fig. 7, 8) The installation consists of two black ribbons and a black cord between them, running along the walls of the exhibition space. Unlike the ribbons, which can be disrupted by a door or window continuing in the next immediate wall, the black cord is always continuous, falling down to the floor when there is no wall to sustain it. The top ribbon has the following sentence printed repeatedly in white: "Aqui os teus sentimentos estéticos são prolongamentos de todos os teus sentidos." (Here your art-form feelings are extensions of all your senses); and on the lower ribbon the sentence: "Após isto as minhas comunicações

18 This is the only example which has the title written in the project both in Portuguese and English.

19 As written in the project-drawing, right below the title.

20 Like all of Carneiro's works, the reference is his own body dimension: the top line (A) is at precisely 1750 millimeters from the floor, which is the artist's height, and the number 250 refers to the diameter of the artist's head. 21 The catalog of this first exhibition displays a reproduction of another drawing representing the plan of the exhibition seen from above and with tree trunks lying horizontally, which did not happen in the installation, where all the trunks were installed vertically. In the following exhibition of $A$ forest for your dreams at, Alternativa Zero at Belém Modern Art Gallery, Lisbon, in 1977, the configuration of the tree trunks was very different from the project-drawing (Cf. http://www. ernestodesousa.com/?p=102): some trunks were grouped together and others were placed horizontally forming a rectangle which delimited the space of the installation, presented in the middle of a large room with works from other artists. For a more complete analysis of these different configurations serão ferramentas para ti mesmo" (After this my communications will be tools for yourself). To read the sentences, the viewer must be close to the walls and walk through the space, thus activating and becoming part of the work.

(fig. 9, 10)

\section{Uma floresta para os teus sonhos (A forest for your dreams), 1970}

Dated and signed in the bottom right corner, with the title written on the top of the sheet, the project-drawing for A forest for your dreams is a "project for the occupation of Buchholz Gallery, Lisbon", where it was materialized for the first time in $1971^{21}$. It presents plans of the exhibition with tree trunks scattered vertically on the floor, creating a dense labyrinth where drawn arrows represent possible passages for the viewer through that "forest". A graphic represents the size variations of the 200 tree trunks that are part of the installation, and in the bottom, a text refers to what the artist calls the "possible connotations" for this work, which broadly reflect his approach to art and its function ${ }^{22}$.

(fig. 11, 12) The installation artwork consists of 200 similar tree trunks, "stripped of cup, roots, branches and holding human intervention", so that the "annulment of each tree individuality [favors] the more general idea of the forest, transported to the inside of the gallery space but still keeping its symbolic integrity" 23 .

of the same work Cf. ROSENDO, Catarina. Alberto Carneiro: os primeiros anos (1963-1975)... op. cit., pp. 157-161.

22 - "The art you look for signifies itself in the rooting of your everyday.

-The compromises of your fruition relates to all your bindings. - Say no to formulas of cultural packaging; use it to find your purity.

-Art is not in the physical presence of the Altamira's bison but in the possession it signifies.

-Art is a "medium" to; its function defines itself in the extension of its own transformation, in the permanent renewal of its field of action.

- The art messages which I propose to you will be significant in the authenticity of the meanings which you find in them. - Lay down in the silence of your day and think that life is more important than every art-for-burgeous-to-enjoy and you will then have your own art, an art for your action”. My translation. 23 ROSENDO, Catarina. Alberto Carneiro: os primeiros anos (1963-1975) ... op. cit., p. 157. 


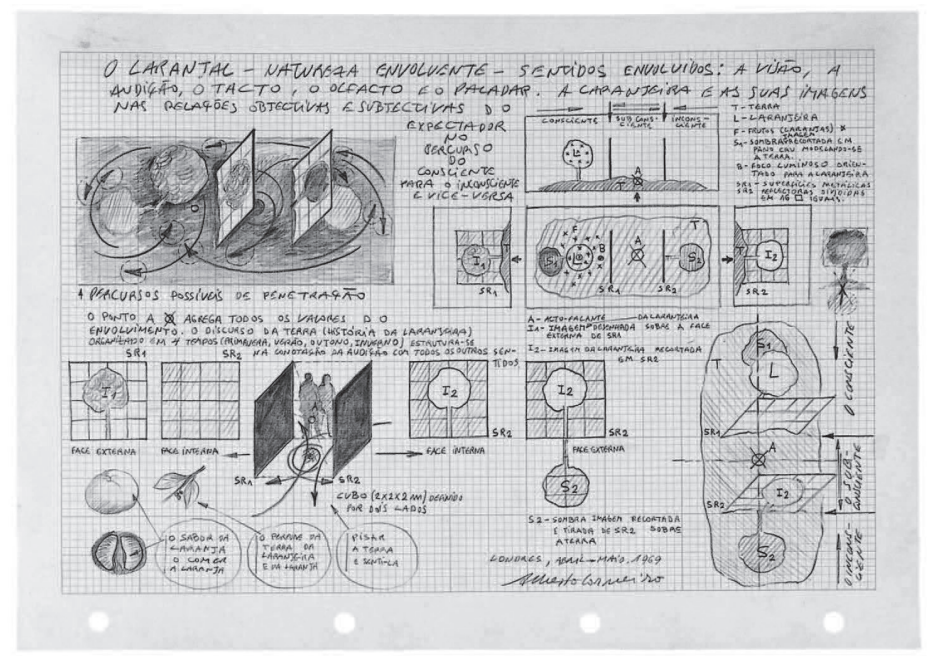

\section{Figure 3}

Alberto Carneiro, The Orange Grove - Involving Nature, 1969 (project-drawing). (c) Coll. Fundação Luso-Americana para o Desenvolvimento, on long-term loan to Fundação de Serralves - Museu de Arte Contemporânea, Porto [Photographer: Laura Castro Caldas/ Paulo Cintra]. Courtesy of FLAD.

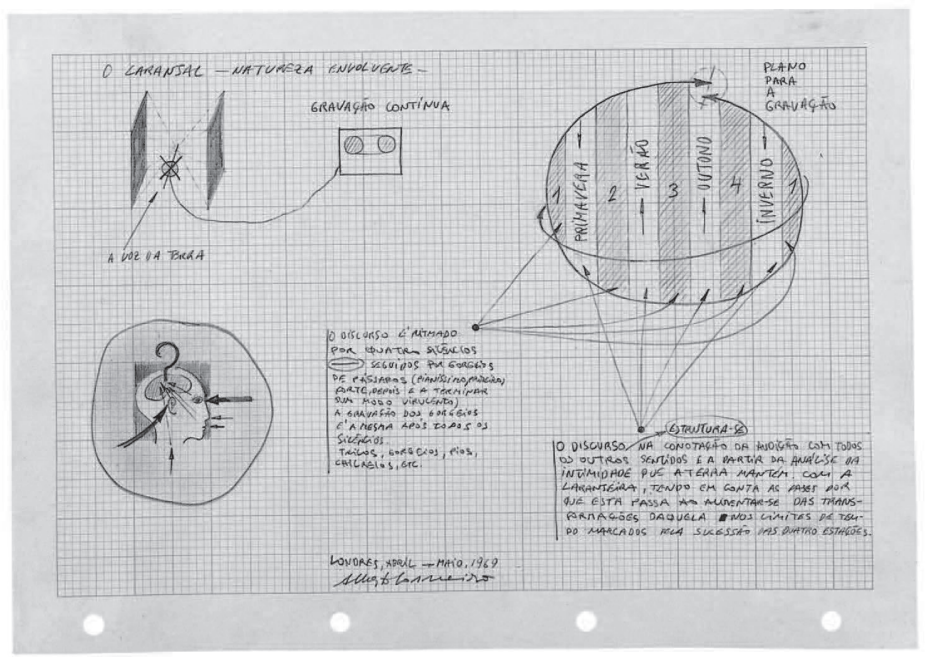

Figure 4

Alberto Carneiro, The Orange Grove - Involving Nature, 1969 (project-drawing). (c) Coll. Fundação Luso-Americana para o Desenvolvimento, on long-term loan to Fundação de Serralves - Museu de Arte Contemporânea, Porto [Photographer: Laura Castro Caldas/ Paulo Cintra]. Courtesy of FLAD. 


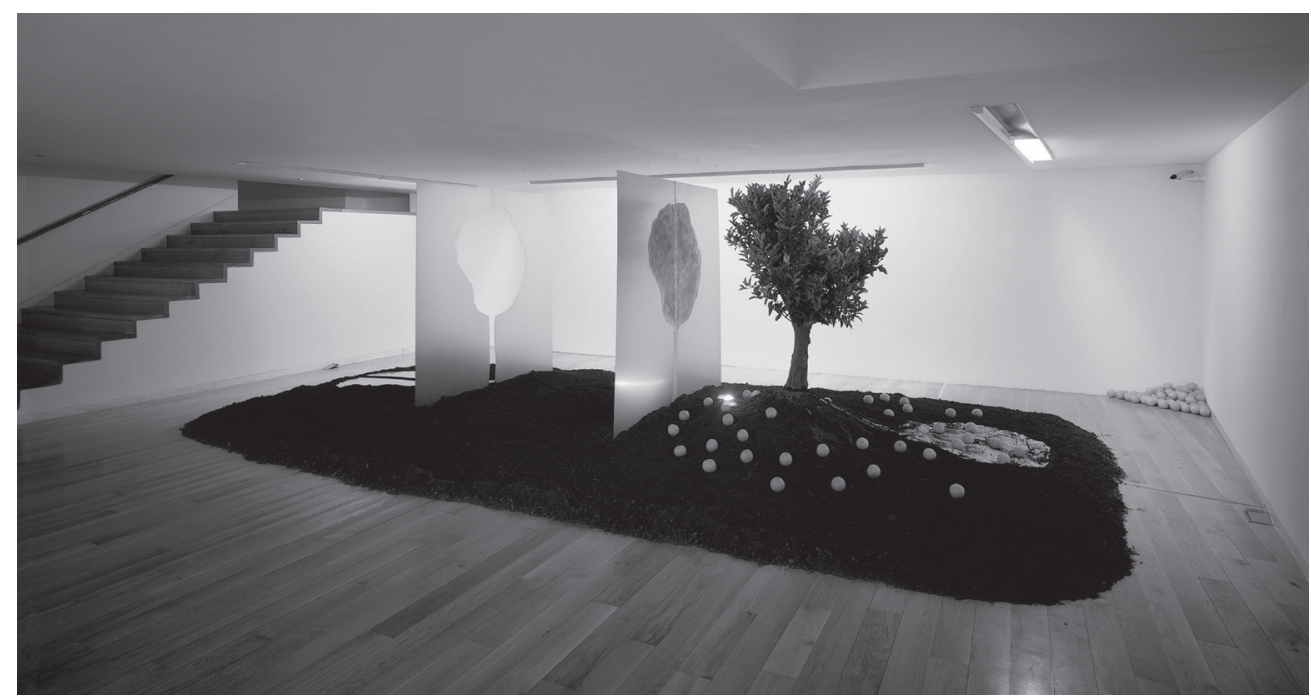

\section{Figure 5}

Alberto Carneiro, The Orange Grove-Involving Nature, 1969. View of the installation at CGAC, 2010.

(c) Photographic Archive, CGAC, Santiago de Compostela [Photographer: Mark Ritchie].

Courtesy of CGAC.

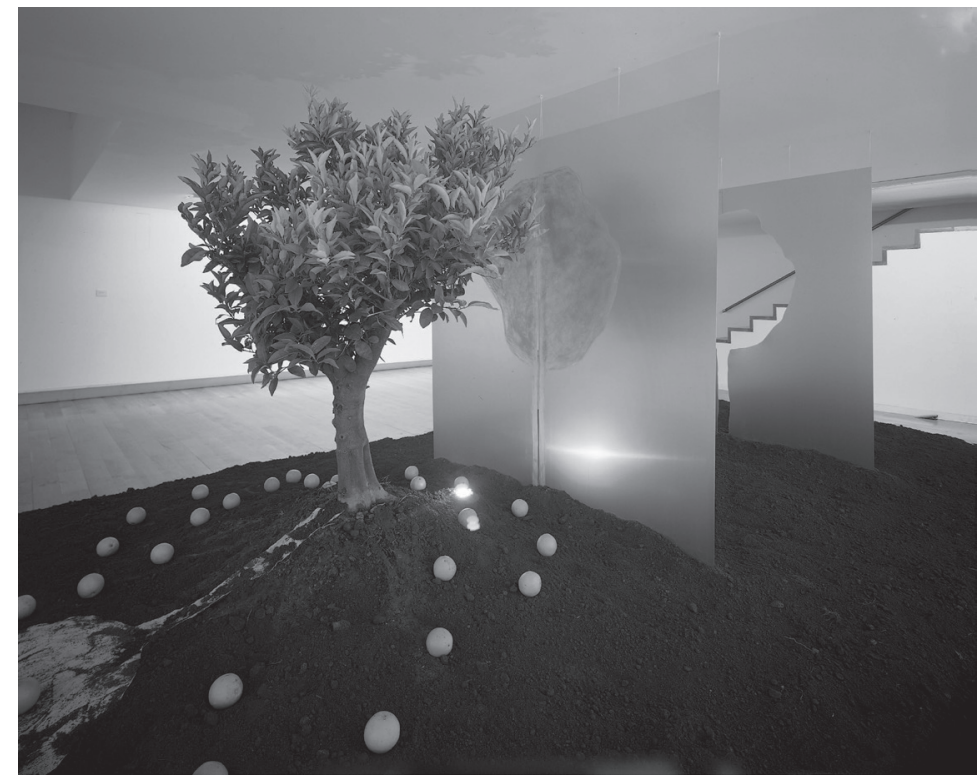

Figure 6

Alberto Carneiro, The Orange Grove-Involving Nature, 1969. Detail of the installation at CGAC, 2010.

(C) Photographic Archive, CGAC, Santiago de Compostela [Photographer: Mark Ritchie].

Courtesy of CGAC. 


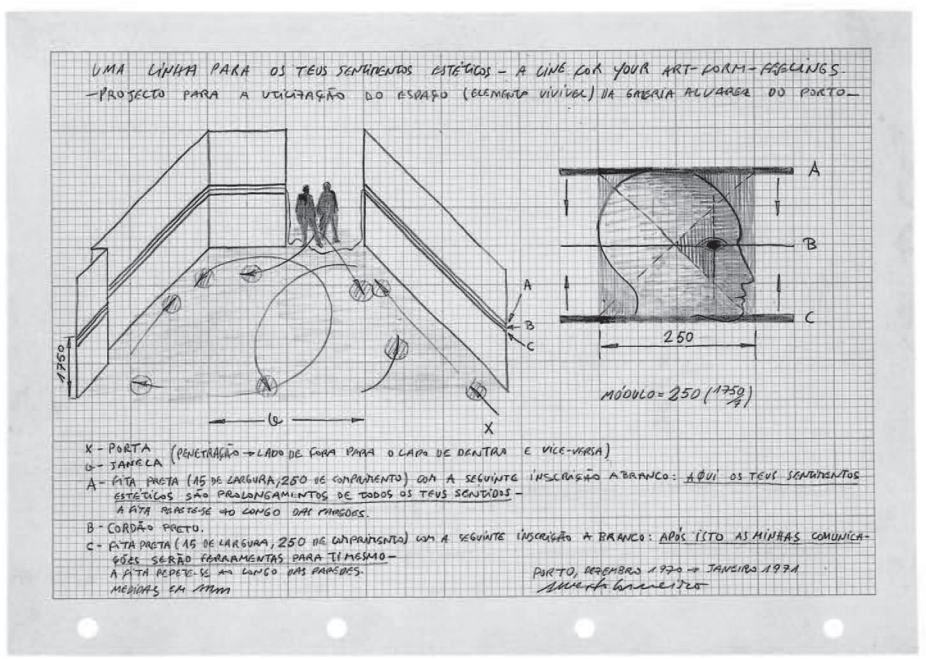

\section{Figure 7}

Alberto Carneiro, A line for you art-form-feelings, 1970-71 (project-drawing).

(C) Coll. Fundação Luso-Americana para o Desenvolvimento, on long-term loan to Fundação de Serralves - Museu de Arte Contemporânea, Porto [Photographer: Laura Castro Caldas/ Paulo Cintra]. Courtesy of FLAD.

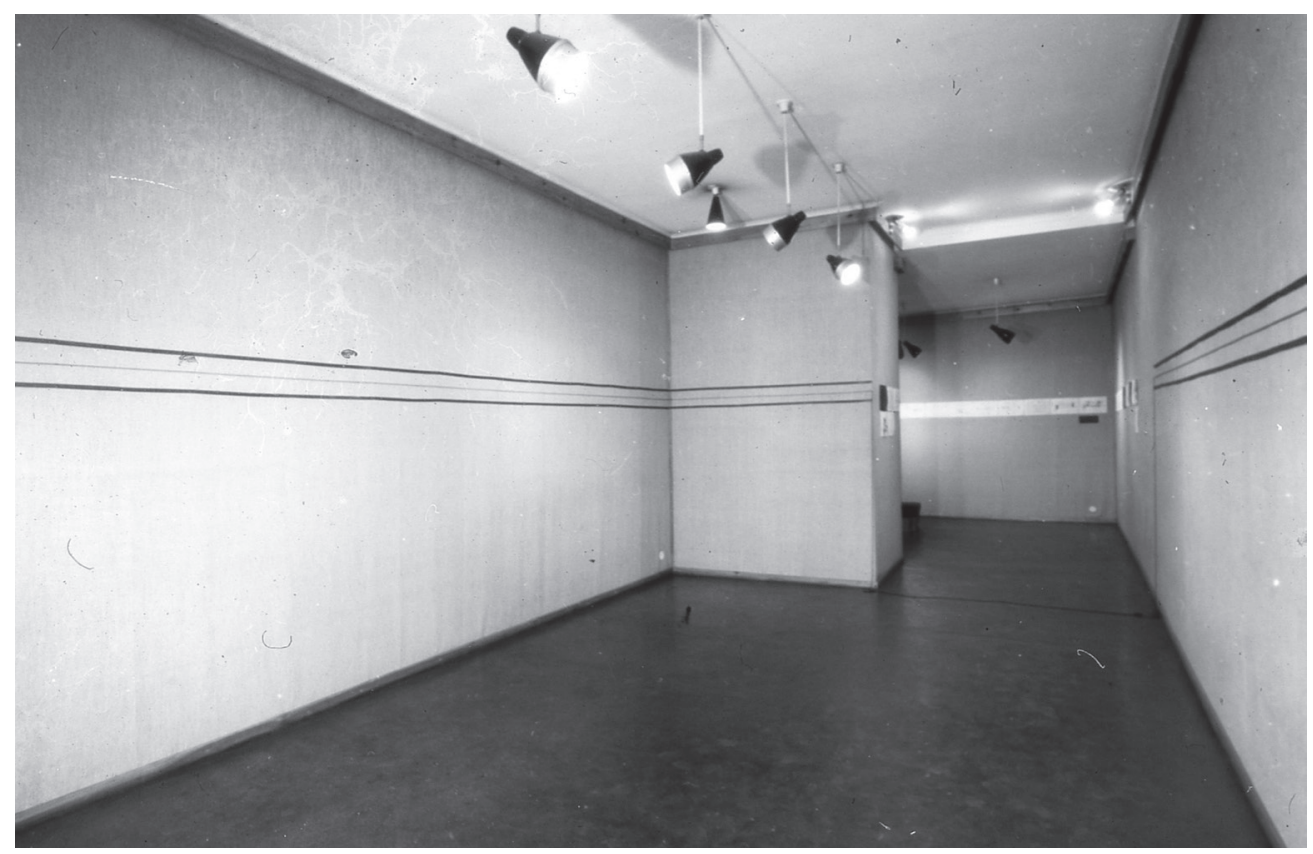

\section{Figure 8}

Alberto Carneiro, A line for you art-form-feelings, 1970-71. Installation view at Alvarez Gallery, Porto, Portugal, 1971.

(c) Alberto Carneiro's Archive. Courtesy of Alberto Carneiro. 
Placed vertically the tree trunks create a dense environment the viewer can enter to physically and symbolically experience the forest within the gallery space.

\section{Project-drawing vs autonomous drawing}

If the artist carries through his idea and makes it into visible art, then all the steps in the process are of importance. The idea itself, even if not made visual, is as much a work of art as any finished product. All intervening steps—scribbles, sketches, drawings, failed work, models, studies, thought, conversations-are of interest ${ }^{24}$.

During the second half of the twentieth century traditional concepts of drawing as an auxiliary medium were subjected to critical analyses by artists who wished to expand it into new possibilities. Being an authentic, immediate, mobile and, economic medium, drawing acquired a new importance by claiming its status as a mediator between the subjective and the objective, the concept and the material, easily translating abstract concepts into form, and often used "to produce works that $[\ldots]$ suggest a level of intimacy and direct encounter with the artists' thoughts and intentions that is less readily apparent in their work in other mediums" 25 .

Artists associated with Minimalism, PostMinimalism and Conceptual Art used drawing in a variety of ways, namely as presentation or autonomous drawings or as studies and sketches for how to proceed to make or construct an artwork. Donald Judd, for example, used drawing as a medium to provide technical instructions, seeing it not as

24 LEWITT, Sol. "Paragraphs on Conceptual Art". In ALBERRO, Alexander, and STIMSON, Blake (Eds.). Conceptual Art: a Critical Anthology. Cambridge, Massachussets and London, England: The MIT Press, 1999, p. 12. 25 MALONE, Meredith. "The Pourous Practice of Drawing: System, Seriality, and the Handmade Mark in Minimal and Conceptual Art”. In NACKMAN, Rachel (ed.). op. cit., p. 3.

26 Ibid.pp. 3-4. an autonomous work of art, but as "necessary supporting material for the creation of his serial sculptural works" ${ }^{26}$.

For artists like Barry Le Va the importance of an artwork rested more on the idea and on the processes of its making than on the final object, and the preparatory or presentation drawings were usually the only remnants and testimonies of that process, thus becoming the artwork themselves.

Sol LeWitt also believed that "the idea of concept [was] the most important aspect of the work" ${ }^{27}$ and used drawing as a means to communicate that concept. For him, as for many other Conceptual artists, the materialization of the idea was not relevant, stating that "When an artist uses a conceptual form of art, it means that all of the planning and decisions are made beforehand and the execution is a perfunctory affair. The idea becomes a machine that makes the $\operatorname{art}^{28}$.

Carneiro's project-drawings share some of 101 these assumptions. The artist himself states that they function as orientation guidelines ${ }^{29}$ that should be considered along with many other factors when installing the work, namely the specific space where the work will be installed and the relation with other works in the exhibition ${ }^{30}$, tying them to Minimal Art. Referring to the project-drawing for The Reedbed, Javier Maderuelo points out that the codes and the profusion of the written sentences denotes the wish to assert a distance from a mere sketch and makes it a work in its own right, its existence not dependant on any later materialization of the installation. It is this "projectual attitude" that connects Carneiro's artistic activity with Conceptual Art. Because the concept is clearly communicated in the

\footnotetext{
27 LEWITT, Sol. "Paragraphs on Conceptual Art". In ALBERRO, op.cit., p. 12.

28 Ibid.

29 OLIVEIRA, op. cit., p. 39.

30 MACEDO, Rita. Desafios da arte contemporânea à Conservação e Restauro. Documentar a arte portuguesa dos anos 60-70. (PhD). Lisbon: Universidade Nova de Lisboa, Faculdade de Ciências e Tecnologia, 2008, p. 256.
} 
project-drawings, their later materialization is a possibility, not a necessity. In addition, besides these conceptual aspects, the project-drawings are also charged with the artist's memories of his experiences of his own body in nature ${ }^{31}$. These drawings are then considered independent and autonomous, despite being essential to understand and construct the installation works ${ }^{32}$.

The project-drawings $s^{33}$ also demonstrate how the artist uses the medium as a means of expression "in which the sheet of paper is understood as a field of action where the imagetic and sensitive conditions of spaces are investigated by reducing the reality to a bi-dimensional plan" ${ }^{34}$. Unlike sketches, which typically must be accomplished quickly in order to catch the fleeting conceptual ideas floating in the mind of the artist ${ }^{35}$, Carneiro's project-drawings are the final product of an intense maturation of a concept, and do not have an unfinished look. They appear complex because of the density of the concepts the artist is trying to communicate and they are all finished works in their own right. Once again, unlike sketches, these drawings are dated and signed, thus asserting themselves as autonomous drawings ${ }^{36}$, and allowing them to be exhibited as such.

During previous centuries drawing functioned "as formal evidence of finished artworks in other media and [was] legitimated in relation to those works—or their absence." ${ }^{37}$ But this assumption is out of step with contemporary

31 MADERUELO, Javier. "Alberto Carneiro. Naturaleza, Árboles y Agua”. In MADERUELO, Javier. Caminos de la escultura contemporànea. Salamanca: Ediciones Universidade, 2012, pp. 269-270.

32 MACEDO, op. cit., p. 241.

33 The few examples described in this paper are just a small example of a vast drawing production (not just project-drawings) which accompanies Alberto Carneiro through his entire career. For a selection of many different kinds of drawings, Cf. for example: Alberto Carneiro. Desenhos, raizes, caules, folhas, flores e frutos. Porto: Quadrado Azul Gallery, 2000, and more recently, ROSENDO, Catarina (ed.) Alberto Carneiro. Árvores, flores e frutos do meu jardim. Desenhos e Esculturas... op. cit..

34 Ibid., p. 122. thinking about drawing and its practice ${ }^{38}$. Carneiro's project-drawings do not need to be legitimated by the materialization of the project in tri-dimensional space because, for the artist "the important thing in the work of art is the assurance that the original concept is kept as a proposal for the viewer." ${ }^{39}$ As Javier Maderuelo concludes, the physical counterpart of the work is then a material witness of a profound reflexive action made on paper $^{40}$. From this point of view, the materialization is secondary and could even be unnecessary. It was this assumption that allowed Carneiro to sell the drawings as autonomous artworks, as will be analyzed in the next section.

Despite their autonomy, the artist never abdicated the "project feature" of these drawings, which is proved by the fact that he always refers to them when discussing their materialization $^{41}$. Their easy reproducibility also allows them to be published in exhibition's catalogues alongside with photographs of the installation artwork. In these cases they are seen as "documents” of the artist's intentions and thoughts, which would help the reader to understand the installation artwork.

\section{Exhibiting drawing vs exhibiting installation artworks}

\author{
The artwork lives effectively of $[. .$.$] the$ \\ successive viewers, by whom it passes, ending \\ in the moment it stops being shown. Not in the \\ moment when it physically vanishes, but in the
}

35 PETHERBRIDGE, Deanna. The primacy of drawing. Histories and theories of practice. London: Yale University Press, 2011, p. 49.

36 Because many sketches were usually not signed, in previous centuries drawing was not theorized or properly studied or collected, and thus not accepted as an autonomous artwork until authenticated. For more on this subject, Cf. PETHERBRIDGE, op. cit.

37 Ibid., p. 9

38 Ibid.

39 Interview to Alberto Carneiro by Cristina Oliveira, São Mamede do Coronado, Portugal, April 5 2012. Unpublished. My translation.

40 MADERUELO, op. cit., p. 282

41 Cf. MACEDO, op. cit., pp. 219-264 and OLIVEIRA, op. cit., pp. 38-60. 


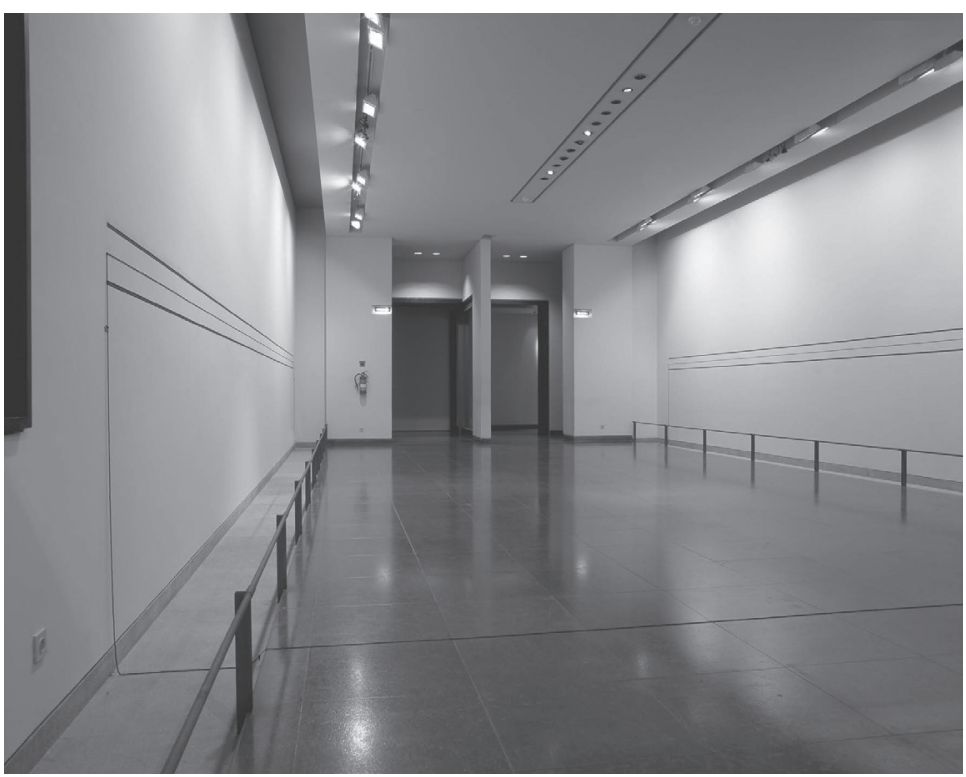

Figure 9

Alberto Carneiro, A line for you art-form-feelings, 1970-71. Installation view at Chiado Museum, Lisbon, Portugal, 2001.

(C) Museu Nacional de Arte Contemporânea - Museu do Chiado [Photographer: Mário Valente]. Direção-Geral do Património Cultural / Arquivo de Documentação Fotográfica (DGPC/ADF).

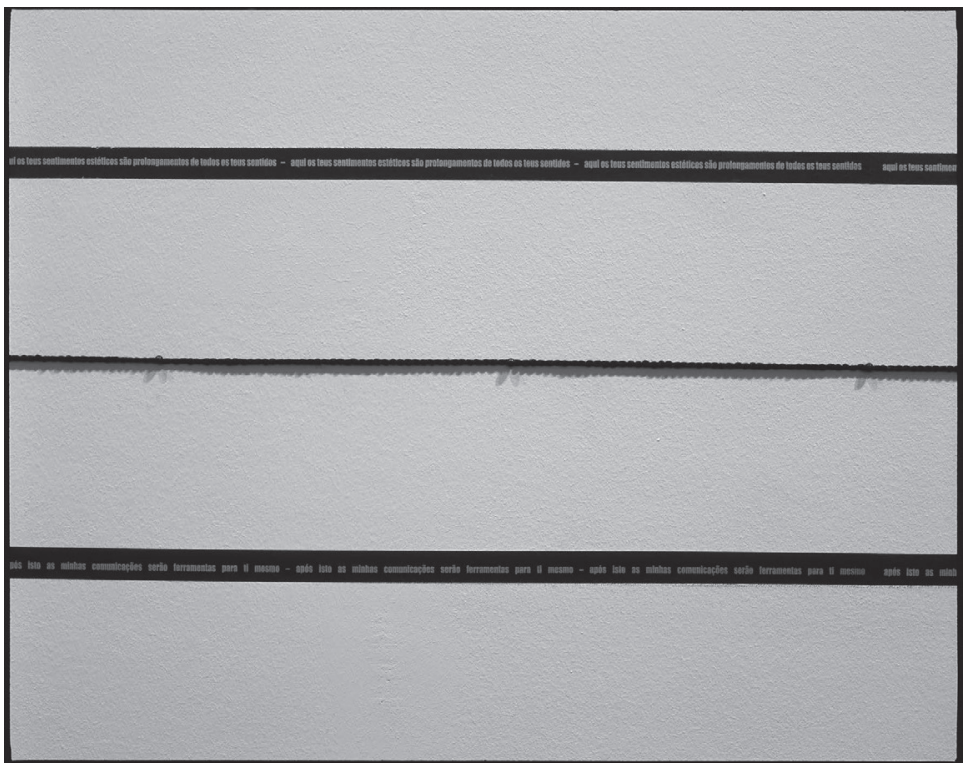

Figure 10

Alberto Carneiro, A line for you art-form-feelings (detail), 1970-71. Installation view at Chiado Museum, Lisbon, Portugal, 2001.

(C) Museu Nacional de Arte Contemporânea - Museu do Chiado [Photographer: Mário Valente]. Direção-Geral do Património Cultural / Arquivo de Documentação Fotográfica (DGPC/ADF). 


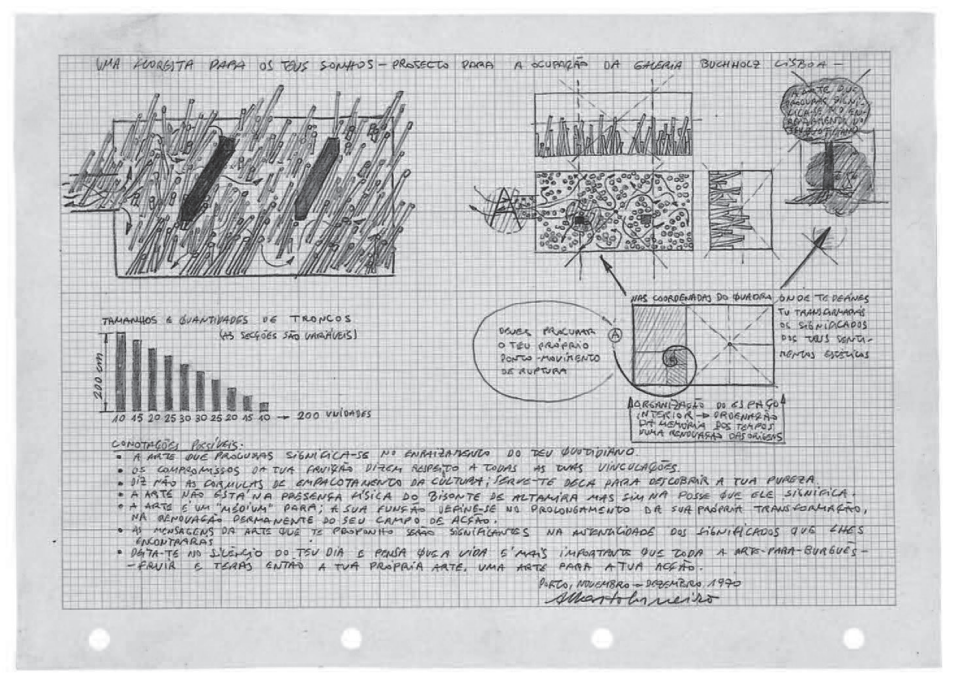

\section{Figure 11}

Alberto Carneiro, A forest for your dreams, 1970 (project-drawing).

(c) Coll. Fundação Luso-Americana para o Desenvolvimento, on long-term

loan to Fundação de Serralves - Museu de Arte Contemporânea, Porto [Photographer: Laura Castro Caldas/Paulo Cintra]. Courtesy of FLAD.

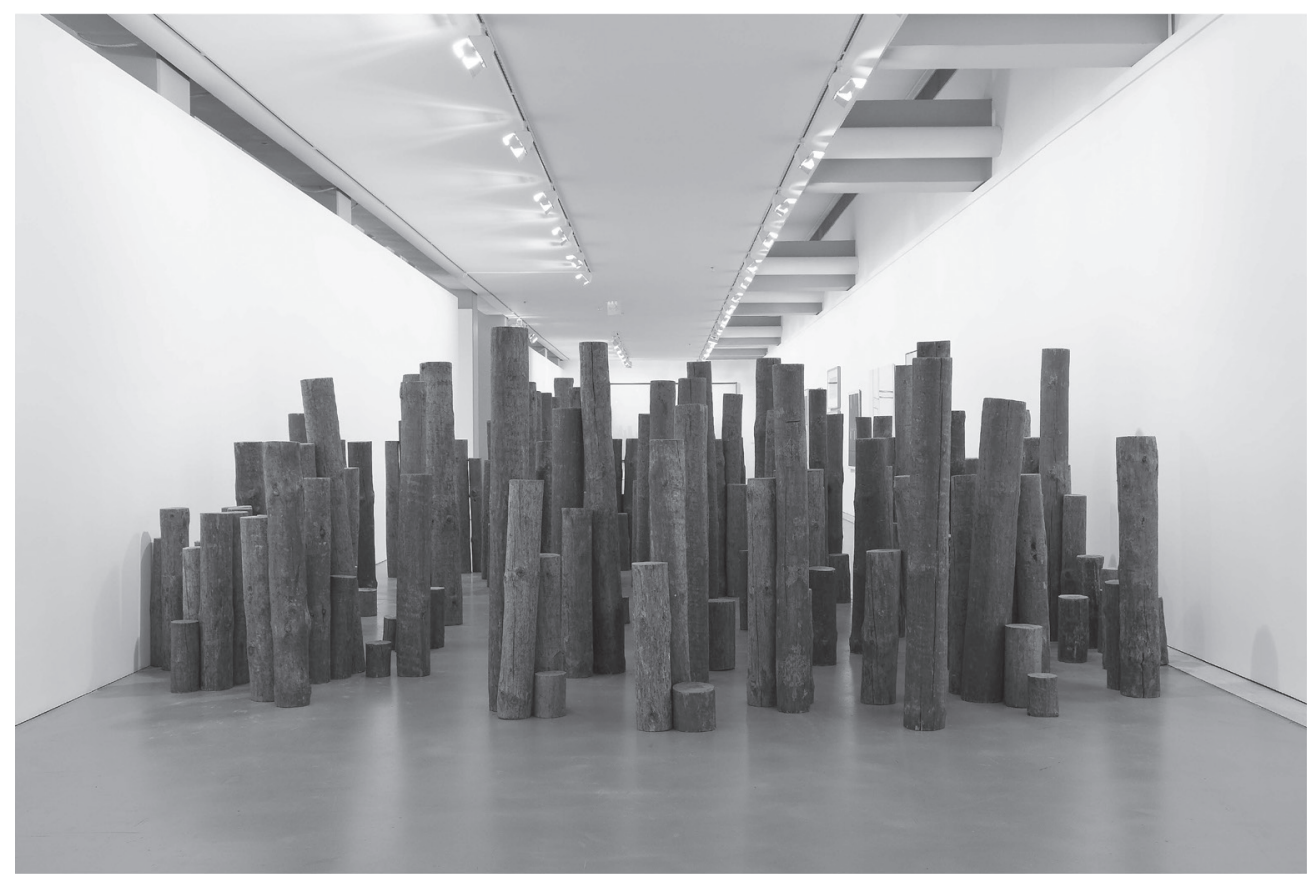

Figure 12

Alberto Carneiro, A forest for your dreams, 1970. View of the installation at Modern Art Center - Calouste Gulbenkian Foundation.

(c) CAM-FCG [Photographer: Paulo Costa]. Courtesy of CAM-FCG. 
moment it stops having viewers, since it has a specific function: to be the vehicle of aesthetic motivations of some kind ${ }^{42}$.

All four project-drawings described above now belong to the art collection of Fundação LusoAmericana para o Desenvolvimento (FLAD) ${ }^{43}$, which focuses on collecting drawings, recognizing the relevance of this practice within contemporary artistic production. By acquiring some of Carneiro's project-drawings (and the artist, by selling them), FLAD attests to their autonomy as independent artworks. This also affects the way they are exhibited: placed in a frame and hung on the exhibition room walls, like any other type of two-dimensional work, without any reference to the existence of the installation artworks ${ }^{44}$.

The artist agrees that the project-drawings contain the essential clues to perceive the concept: "[...] Someone familiar with these things can understand it without the physical existence of the work" ${ }^{45}$. Thereby, project-drawings can also be exhibited as documentation works: shown as the prevailing feature of a temporary installation or as guidelines for their construction, as exemplified in the group exhibition Habitar(s), in 2014, at Porto, where they were displayed in horizontal showcases. In fact, according to the artist, the project-drawing is assumed as such " $[. .$.$] because the artwork has a limited$ temporality, and the project [-drawing] exists as a graphic means to communicate the way to make a new work in which the concept is the same" ${ }^{46}$.

42 Interview to Alberto Carneiro by Cristina Oliveira, São Mamede do Coronado, Portugal, April 5 2012. Unpublished. My translation.

43 Portuguese-American Foundation for Development.

44 In the group exhibition Paisagens no singular, 1999, interestingly the project-drawings where exhibited side by side with a photography of the respective installations. Cf. Paisagens no singular. Lisbon: Instituto de Arte Contemporânea, 1999.

45 OLIVEIRA, op. cit., p. 54.

46 OLIVEIRA, op. cit., pp. 47-48.

47 Cf, for example, SARDO, Delfim. "Landscape vs passage.” In SILVÉRIO, João (ed.). Passagem. Obras da coleção da Fundação Luso-Americana para o Desenvolvimento. Lisbon:
About the relationship between project-drawing and its materialization in space as an installation artwork, Delfim Sardo describes Carneiro's "threefold relationship with drawing as a specific device":

First, drawing appears as a spatial representation of the situation the artist wishes to generate, sometimes carried out in great detail, $[\ldots]$

Secondly, the drawing is also the graphic execution of an inscription on a support, as far as representations of space, text, plans and diagrams combine in a visual organisation that defines a certain heuristics, as well as an aesthetics.[...]

Thirdly, this drawing leads to a second drawing, a drawing that is spatial, participative, and clearly embodied, which will lead to the action proper, since it details the placement of the installation's elements, their spatial migration and the spectator's itinerary - as such, the drawing becomes a "forthcoming" process ${ }^{47}$.

The four installation artworks discussed here are some of the most important contemporary Portuguese examples of installation art, and belong to some of the major institutions dedicated to contemporary art in Portugal and Spain $^{48}$.

Unlike drawing, collecting and exhibiting installation artworks demands a redefinition of traditional museum practices, and Carneiro's works of this kind are clear examples of the challenges they present for museums to

Fundação Luso-Americana para o Desenvolvimento, 2008, pp. 50-51.

48 The Reedbed: memory-metamorphosis of an absent body, 1968, belongs to Caixa Geral de Depósitos (CGD) Collection, Lisbon, since 1995; The Orange Grove: Involving Nature, 1969, is part of the Centro Galego de Arte Contemporánea (CGAC) collection, Santiago de Compostela, since 2001; A line for your art-form-feelings, 1970-71 belongs to the National Museum of Contemporary Art (MNAC) - Chiado Museum, Lisbon, since 2001; and finally, A forest for your dreams, 1970 is part of the Modern Art Center-Calouste Gulbenkian Foundation (CAMFCG) Collection since 1996. 
preserve and exhibit them. Works like The Reedbed or The Orange Grove can be re-installed at any time and in different exhibition spaces and, because they are installation artworks, they are always dismantled after each exhibition, and some materials (the reeds, the dirt, the oranges) need to be replaced in each iteration $^{49}$. Jill Sterret explains that:

$[\ldots]$ we actually have to test our knowledge of installing those pieces. They're only parts in storage until we put them together. They become the art according to a set of instructions that we get from the artist. If you put the work in storage and don't display it for ten years, you've diminished your ability to keep it because you might not be able to install it properly ${ }^{50}$.

Those "instructions that we get from the artist", in the works in question, are the project-drawings which should be known and studied so that their materialization respects the propositions of the artist. The collectors of the installations do not need to own the drawings, but must recognize them as important parts of the process of production and installation of the work.

As mentioned before, Carneiro sees the project-drawings not as a rigid set of instructions, but as orientation guidelines for their eventual materialization, thus accepting some modifications due, for example, to the space where the work is installed:

I'm faithful to the principle of spatial articulation and consider that the most important thing is not the shape but the relation between things. There are always changes, but once again, the concept is

49 The reeds for The Reedbed are in variable number according to the dimensions of the exhibition room. Also, because they are easily infested with insects, they should not be kept in museum storage. As for The Orange Grove, the only material the museum retains is the audio recording. 50 Getty Conservation Institute. Competing Commitments: A Discussion about Ethical Dilemmas in the Conservation of Modern and Contemporary Art. Conservation Perspectives. http://getty.edu/conservation/publications_resources/newsletters/24_2/dialogue.html (retrieved in September, 2014). 51 Ibid., p. 39. that previous one, without deviations. $[\ldots]$ the project remains to answer to a determined concept, to a set of ideas, or processes, or relations ${ }^{51}$.

Although the original concept is present in the project-drawings, exhibiting the installation artworks reveals aspects not perceived in them which can only be explored in the physical exhibition space. On the other hand, even if exhibited as independent artworks, the meaning of the project-drawings can also be potentiated by the simultaneous exhibition of the installation artworks. Therefore, when exhibited together, both devices always enrich each other's readings, revealing new potentials only perceived in the exhibition space.

\section{Interpretation vs experience}

$$
\begin{aligned}
& \text { The best museums of the future will [...] } \\
& \text { seek to promote different modes and levels } \\
& \text { of 'interpretation' by subtle juxtaposition } \\
& \text { of 'experience'52. }
\end{aligned}
$$

\section{The drawing is not made as something which} prepares sculpture, but as a means which favors its developments ${ }^{53}$.

I believe that the simultaneous exhibition of both drawings and installation artworks creates an opportunity to engender new readings for both artworks in confrontation, promoting, as Nicolas Serota defended for the new museums ${ }^{54}$, new levels of interpretation crossed with new experiences within the exhibition space.

52 SEROTA, Nicholas. Experience or Interpretation. The Dilemma of Museums of Modern Art. London: Thames \& Hudson, 1996, p. 55.

53 CARNEIRO, Alberto. Das notas para um diário e outros textos. Antologia. Lisbon: Assírio \& Alvim, 2007, p. 161. 54 SEROTA, op. cit. 
According to Alberto Carneiro, his work is essentially "the place or places where the aesthetic encounter between it and its viewer occurs. It's the viewer who provides the work with its level of aesthetic communication" 55 . Denying any pedagogical attempt to explain or interpret his own work, the artist leaves this task to the viewer himself, just providing him with the necessary tools for that aesthetic encounter: he enables the viewer to penetrate, touch and thus activate and experience the space which they share with the installation artwork; and simultaneously offers clues, through the project-drawings for the interpretation of the works. It is this duality between experience and interpretation that a simultaneous exhibition of both devices can heighten.

With the examples described in this paper, the interactions between the viewers and the works in the exhibition space occur in different ways. The artist communicates through the project-drawings, which "exist so that anyone could do the work $[\ldots]]^{\prime 56}$, enabling the viewer to mentally construct it.

I always wish my sculptures to be a place for others, a motivation for a creative act in the contemplation. I try to communicate my world, which may well not be the world found by a given beholder if his education and aesthetic necessities do not coincide with mine. I consider that the work of art should give itself until the point of being able to be recreated by who enjoys it. That authenticates the communication between the creator and the beholder within the created thing ${ }^{57}$.

The use of the written word plays a role here. The project-drawings are not only constituted by schemes, plans and small pictures, but are also filled with sentences and annotations, some of which directly address the viewer. Titles like A forest for your dreams or A line for your

55 MACEDO, op. cit., pp. 241-242

56 OLIVEIRA, op. cit., p. 42.

57 CARNEIRO, op. cit., p. 20.

58 MACEDO, op.cit., p. 241.

59 Ibid. art-form-feelings [my emphasis], address both the viewer who reads them, as the viewer who is invited to enter the installation and become part of it. As we saw, the project-drawing of A forest for your dreams has a text with "possible connotations" which is assumed as an extension or an addition in a different language ${ }^{58}$, thus connecting the two instances of the work through the active participation of the viewer in the exhibition space.

In some of the installations the viewer is invited to enter the work, thus becoming part of it and enhancing a theatrical element also inherent to Carneiro's many installation artworks. Carneiro explains that this "is one of the principles I place in what I do at that time [at the end of the 1960s]" 59 . A line for your art-formfeelings exemplifies this use of space and the importance of the presence of the viewer in its activation for the completion of the work. This is an example of what Robert Morris called presentness: "the intimate inseparability of the experience of physical space and that of an ongoing immediate present. Real space is not experienced except in real time" ${ }^{00}$. Once again, it is the project-drawing that gives clues to the desired experience: the activation of space by the viewer is indicated by the possible paths drawn in the paper.

Another level of interaction might happen with the simultaneous exhibition of both devices. If the project-drawings are sufficient to perceive the concept of the work, there is one aspect that, for Carneiro, can only be appreciated with its materialization: " $[\ldots]$ the spatiality of the artwork. That is inevitable. It's fundamental; $[\ldots]$. Because the concept we can completely read it in the project. But not the profound experience. Sensibility is sensibility; we need to touch things" ${ }^{61}$. The Reedbed is a clear example: the project-drawing reveals the memories of the artist inherent to the creation of the work, and necessary for its

60 MORRIS, Robert. "The Present Tense of Space". In Continuous Project Altered Daily: The Writings of Robert Morris. Cambridge, Massachusetts and London, England: The MIT Press, 1993, p. 177.

61 OLIVEIRA, op.cit., p. 45. 
understanding, but the installation artwork (an entire exhibition room filled with reeds) enables a unique spatial experience for the viewer who enters it.

As already mentioned, besides formal instructions the project-drawings are also filled with clues that allow the creation of a reflective space for the viewer within the exhibition space shared between him and the installation works. The Orange Grove is an example. Bringing to the gallery space natural elements such as the tree, the earth and the oranges, and installing them together with other elements (such as light and sound), Carneiro's goal was to create a complete environment, activating all of the viewer's senses. If faced only with the installation, the viewer would certainly feel themself immersed in that natural environment inside the gallery, but they would probably feel reluctant to take an orange and eat it there, only because they may not know it was permitted, and thus not activating the sense of taste, as the artist intended. In the presence of the project-drawing alongside the installation the viewer could, obviously, feel the same constraints in eating the orange; but at least they would be aware that such was the goal of the artist.

\section{Conclusion}

Robert Morris wrote that "Duchamp noted those noises that intervened between the artist's intention and realization and again between the realization and the public interpretation" ${ }^{62}$. The exhibition space is the place where public interpretation happens, it can also be the place where those "noises" may be reduced. The examples in this paper describe the clear advantage of knowing both project-drawing and installation artwork in order to fully understand the artist's initial concept.

Accepting the project-drawings as autonomous artworks, they have, however, a simultaneous "project feature" that inevitably ties them up with the materialization of the concept presented in them. On the other hand, the fact that all the works belong to different museum collections attest to their autonomy as independent artworks. Therefore, the exhibition can be the privileged place where the viewer is able to confront both devices-project-drawings and installation artworks-and explore the potential dialogues between them, thus creating a reflective space where the communicability and theatricality inherent to Carneiro's practice can be catalyzed.

That reflective space can assume different features. First, considering the project-drawings as autonomous artworks, their exhibition as such will always activate a new place in the imagination of the viewer who, according to the artist, must create the work in their mind.

Secondly, the spatial and physical experience of the viewer within the exhibition space is only possible with the installation artwork that adds spatiality, a feature that cannot be appreciated in the project-drawings.

Third, as these installations are ephemeral artworks, the project-drawings are the permanent parts of the work. Because all the installations belong to museum collection's the drawings should be kept to inform any future re-installation, functioning as essential conservation documents necessary for the preservation of the concept for all future materializations.

Finally, a pedagogical potential can also be distinguished within the exhibition space taken as a medium for reflection. Carneiro is, as we saw, constantly addressing himself to the viewer of his works, seeking that they experience the works in a more profound way than mere visualization. If the installations alone give the viewer a full physical experience, the project-drawings provide clues for interpretation, thus enriching the viewer's experience and understanding of the works:

[...] art manifests itself as communication; as support and means of realization 
and transformation of the aesthetic conscience, in the mutation of the collective senses, of its appointed author and of all beholders, which would always find new significations in it ${ }^{63}$. 


\section{Bibliography}

BUTLER, Cornelia H. After image. Drawing through process. Los Angeles: Museum of Contemporary Art, 1999.

CARNEIRO, Alberto. Das notas para um diário e outros textos. Antologia. Lisbon: Assírio \& Alvim, 2007.

FERNANDES, João. "Alberto Carneiro: The Evidence of Nature in the Construction of the Human Relationship with the World". In Alberto Carneiro. Santiago de Compostela: Centro Galego de Arte Contemporánea, 2001, pp. 110-115.

Getty Conservation Institute. Competing Commitments: A Discussion about Ethical Dilemmas in the Conservation of Modern and Contemporary Art. Conservation Perspectives. http://getty.edu/conservation/publications_ resources/newsletters/24_2/dialogue.html (retrieved in September 2014).

LEWITT, Sol. "Paragraphs on Conceptual Art”. In ALBERRO, Alexander and STIMSON, Blake (eds.). Conceptual Art: a Critical Anthology. Cambridge, Massachussets and London, England: The MIT Press, 1999. pp. 12-16.

MACEDO. Rita. Desafios da Arte Contemporânea à Conservação e Restauro. Documentar a Arte Portuguesa dos anos 60-70. $(\mathrm{PhD})$. Lisbon: Universidade Nova de Lisboa, Faculdade de Ciências e Tecnologia, 2008.

MADERUELO, Javier. "Alberto Carneiro. Naturaleza, Árboles y Agua”. In MADERUELO, Javier. Caminos de la escultura contemporànea. Salamanca: Ediciones Universidad, 2012, pp. 267-268.

MALONE, Meredith. "The Porous Practice of Drawing: System, Seriality, and the Handmade Mark in Minimal and Conceptual Art”. In NACKMAN, Rachel (ed.). Notations: Contemporary Drawing as Idea and Process.
Washington: Mildred Lane Kemper Art Museum, 2012. http://notations.aboutdrawing.org/essay/ (retrieved in April 2015).

MELO, Alexandre. "O viandante esclarecido." In Alberto Carneiro. Lisbon: Assírio \& Alvim, 2003, pp. 11-19.

MORRIS, Robert. "The Present Tense of Space." In Continuous Project Altered Daily: The Writings of Robert Morris. Cambridge, Massachusetts and London, England: The MIT Press, 1993, pp. 175-209.

OLIVEIRA, Cristina. A preservação da arte efémera de Alberto Carneiro com aplicação ao caso de Árvore jogo/lúdico em sete imagens espelhadas. (Master's Degree thesis in Conmservation and Restoration). Lisbon: Universidade Nova de Lisboa, Faculdade de Ciências e Tecnologia, 2009.

PETHERBRIDGE, Deanna. The primacy of drawing. Histories and theories of practice. London: Yale University Press, 2011.

ROSENDO, Catarina. "A garden as far as the eye can see: paradise on earth". In ROSENDO, Catarina (ed.) Alberto Carneiro. Árvores, flores e frutos do meu jardim. Desenhos e Esculturas. Lisbon: Documenta, Fundação Carmona e Costa, 2015, pp. 183-196.

ROSENDO, Catarina. Alberto Carneiro: os primeiros anos (1963-1975). Colecção Teses. Lisbon: Edições Colibri e IHA - Estudos de Arte Contemporânea, FCSH - UNL, 2007.

SARDO, Delfim. "Landscape vs passage." In SILVÉRIO, João (ed.). Passagem. Obras da coleção da Fundação Luso-Americana para o Desenvolvimento. Lisbon: Fundação Luso-Americana para o Desenvolvimento, pp. 49-60.

SEROTA, Nicholas. Experience or Interpretation. The Dilemma of Museums of Modern Art. London: Thames \& Hudson, 1996. 
SILVA, Raquel Henriques da. "Alberto

Carneiro: The Bodies of Sculpture." In Alberto

Carneiro, Santiago de Compostela: Centro

Galego de Arte Contemporánea, 2001,

pp. 32-39. 


\section{L'exposition en tant que médium: le dialogue entre l'artiste, l'espace, l'œuvre et l'observateur participant}

Cet article explore la notion d'exposition comme une occasion de révéler et de mettre en valeur le sens des œuvres d'art tout en créant un espace réflexif où le visiteur peut dialoguer et entrer en relation avec ces dernières. Les aspects clés de la production et de la pratique du sculpteur portugais Alberto Carneiro sont analysés afin de démontrer comment ils sont déployés dans l'espace d'exposition.

La production de Carneiro peut être associée à l'art conceptuel tout en étant ancrée dans une forte matérialité. Son travail est souvent situé hors site et ses installations précédées par ce que l'artiste qualifie de dessins-projets. Les feuilles de papier quadrillé qu'il utilise à cet effet sont remplies de notes qui aident à élucider les concepts inhérents à l'origine de ses créations et à leur installation dans l'espace d'exposition. Elles contiennent des détails de ses œuvres, recensent les matériaux employés, les schèmes de la distribution spatiale des éléments, les dimensions de certaines composantes, les trajectoires possibles du visiteur, ainsi que des phrases et des pensées formulées par l'artiste. Tous les aspects de ses dessins-projets complexes s'unissent pour révéler le processus de réflexion intense qui sous-tend ses créations. Le travail subséquent d'installation, qui amène habituellement des éléments de la nature dans le musée (arbres, roches, fruits), est la matérialisation d'une investigation profonde de l'espace et de ses relations avec chaque élément de l'œuvre, ainsi qu'avec le corps et l'esprit tant de l'artiste que de l'observateur.

Un des aspects communs aux deux dispositifs (dessins-projets et installations) est l'emploi de l'écrit pour établir un dialogue avec l'observateur participant, et ce, non seulement dans les titres qui s'adressent personnellement à lui, mais aussi dans les annotations des dessins-projets et les phrases de certaines installations. Tous requièrent la présence de l'observateur participant dans l'espace qu'il partage avec les œuvres, de même que les expériences des visiteurs dans la nature (la marche, le repos dans l'herbe et la cueillette des fruits). Cette façon de communiquer est inhérente à la genèse des dessins-projets et des installations dont l'action est intensifiée lorsqu'ils sont exposés simultanément. Cependant, malgré leur évidente connexion, ce sont des créations indépendantes: ils appartiennent à différentes collections et sont généralement exposés séparément. En faisant de l'espace d'exposition un lieu de réflexion, cet article analyse comment la confrontation entre les deux peut activer de nouveaux dialogues et de nouvelles perspectives, tout en renforçant l'objectif premier de l'artiste qui est celui de la communicabilité de ses pièces.

Après la présentation des œuvres retenues en exemple, l'auteur explore dans cet article le potentiel des nouvelles interprétations que le médium de l'exposition peut générer. L'artiste cherche à faire de chaque réinstallation une expérience nouvelle en matérialisant les concepts explorés dans les dessins-projets à même l'espace privilégié de l'exposition. Si, comme Carneiro l'avance, le dessin n'est pas conçu comme quelque 
chose qui prépare à la sculpture, mais plutôt comme un moyen qui favorise son développement, l'exposition simultanée de ces deux composantes générera toujours un nouvel espace de réflexion pour une compréhension approfondie des concepts de l'artiste, de ses intentions et de ses processus. 